\title{
Meat yield of culled cow and steer carcasses
}

\section{Leonir Luiz Pascoal ${ }^{1}$, José Fernando Piva Lobato ${ }^{2}$, João Restle ${ }^{3}$, Ricardo Zambarda Vaz ${ }^{4}$, Fabiano Nunes Vaz $^{4}$}

\author{
1 UFSM. \\ 2 UFRGS. Bolsista do CNPq. \\ 3 UFG. Bolsista do CNPq. \\ 4 PROGEPEC Consultores Associados, Santa Maria - RS.
}

ABSTRACT - The experiment evaluated the meat yield of prepared beef cuts, bone and trimmings of steer and culled cow carcasses. Culled 72-month-old Braford cows, $496 \mathrm{~kg}$ live weight and 36-month-old steers, $494 \mathrm{~kg}$ live weight were used, all from the same herd and finished on ryegrass pasture. A randomized complete design, with two treatments and 15 replications, was used. Hot carcass weight was lower for cows $(248 \mathrm{~kg}$ ) than for steers (263 kg). Steer carcasses presented better conformation, lower chilling loss, shorter (128.6 vs. $137.7 \mathrm{~cm})$, with longer and thicker limbs compared to cows and similar fat finishing. Steer carcasses showed, compared to cow carcasses, always in the same order, similar side cut yield (13.5 vs. 13.4\%), higher forequarter yield (38.4 vs. 37.2\%), and lower hindquarter yield (48.1 vs. 48.9\%), resulting lower yields of the sub-primal cuts full rump and sirloin, lower rump UK trim, rump tail and striploin. Steer and cow carcasses were similar in total yield of prepared meat cuts (77.8 vs. $77.6 \%)$, discarded bone (17.4 vs. 17.9\%), discarded trimmings (4.54 vs. $4.09 \%$ ), and losses inherent to the deboning process (0.34 vs. $0.34 \%$ ). The results showed that cow carcasses are longer, have shorter and thinner limbs, have higher hindquarter and lower of forequarter yields, but the total yield of prepared meat cuts were similar between cow and steer carcasses.

Key Words: Braford, commercial cuts, deboning, hindquarter, primal cuts, retail cuts

\section{Rendimento de cortes preparados de carcaças de vacas e de novilhos}

RESUMO - Avaliaram-se os rendimentos de cortes cárneos preparados, de osso e de retalho descartado das carcaças de animais de novilhos e vacas de descarte. Utilizaram-se 15 vacas de 72 meses com peso vivo de $496 \mathrm{~kg}$ e 15 novilhos de 36 meses com peso vivo de $494 \mathrm{~kg}$, todos da raça Braford e de mesmo rebanho, terminados em pastagem de azevém. O experimento foi realizado em delineamento inteiramente casualizado, com duas categorias animais, cada uma com 15 repetições. O peso de carcaça quente das vacas de descarte $(248 \mathrm{~kg}$ ) foi inferior ao dos novilhos (263 kg). As carcaças dos novilhos apresentaram melhor conformação, com menor quebra no resfriamento, e foram mais curtas (128,6 vs 137,7 cm), com membros mais longos e espessos em comparação às carcaças das vacas. A porcentagem de gordura de cobertura foi similar entre as categorias. Em comparação às vacas de descarte, os novilhos apresentaram rendimento similar de costilhar (13,5 vs $13,4 \%)$, maior de dianteiro (38,4 vs 37,2\%) e menor de serrote (48.1 vs $48.9 \%$ ). Novilhos apresentaram menor rendimento de alcatra e lombo e menor rendimento de miolo da alcatra, maminha e contrafilé. As carcaças de vacas e de novilhos são similares quanto aos rendimentos totais de cortes cárneos preparados (77,8 vs 77,6\%), osso descartado (17,5 vs $17,9 \%)$, retalho descartado (4,54 vs 4,09\%) e perdas inerentes (0,34 vs $0,34 \%)$. Vacas têm carcaça mais comprida, membros mais curtos e finos, maior rendimento de serrote, menor de dianteiro e similar de costilhar, mas o rendimento total de cortes cárneos preparados é similar ao de carcaças de novilhos.

Palavras-chave: Braford, cortes comerciais, cortes primários, desossa, porção comestível, serrote

\section{Introduction}

Packaged deboned cuts are the main products of beef of packing plants with federal inspection in Brazil. Brazilian farmers and packing plants have shown interest in research to identify biotypes producing carcasses with high total yield of ready-to-cook cuts and high value cuts.

The yield of prepared beef cuts is influenced by factors such as age, sex, weight, conformation, finishing, genotype and growth curve, which can be evaluated in vivo or in the carcass. 
The absence of difference in total cut yield between cows and steers does not mean that the meat from these animals presents the same qualitative, commercial, and economic value, which is ultimately determined by the price paid to the farmer for the total and individual yield of the most valuable cuts, and the potential differences in sales price and benefits.

Packing plant tables of prices paid to farmers show that, both historically and today, the value paid for steers is $10-14 \%$ higher compared to females on live weight basis, and $4-8 \%$ higher, considering young and old cows and heifers, on carcass weight basis. The argument is that females, whether cows or heifers, have lower deboned yield, and less tender meat in the case of cows.

The objective of this study was to determine the possible differences in total and individual yield of primal cuts and ready-to-cook cuts between cows and steers derived from the same herd.

\section{Material and Methods}

Braford cows and steers, raised and finished on a commercial farm in Rosário do Sul, Rio Grande do Sul, Brazil, were used. The animals were weaned at seven months of age and finished on ryegrass pasture (Lolium multiflorum Lam). Cows were slaughtered at an average age of 72 months, and steers at 36 months of age, which corresponds to the ages when $90 \%$ of the females and $70 \%$ of the males are usually slaughtered in the region.

The animals were slaughtered in a local commercial packing plant in August 2007, according to the regulations of the Brazilian Federal Inspection System (SIF 1733). The carcasses were then chilled between -2 and $2^{\circ} \mathrm{C}$ for 48 hours, when they were weighed to determine cold carcass weight. Carcass conformation was subjectively assessed by a panel of three trained evaluators, according to the methodology proposed by Müller (1987). Fat cover was subjectively evaluated according to the scale used by the packing plant where the animals were slaughtered by the same evaluators. This scale classifies fat cover according to the following scores: 4 = excessive $(>8 \mathrm{~mm}) ; 3=$ excellent $(7-8 \mathrm{~mm}) ; 2=$ good $(5-6 \mathrm{~mm}) ; 1=\operatorname{regular}(3-4 \mathrm{~mm})$; and $0=$ insufficient $(<3 \mathrm{~mm})$. It must be mentioned that the evaluators were researchers trained in the assessment of beef carcasses.

The following carcass measurements were determined: carcass length, from the cranial edge of the intermediate part of the first rib to the cranial edge of the pubis; hindquarter length, from the cranial edge of the pubis until the tibial-tarsal joint; forequarter length, from the olecranon tuberosity until the distal extremity of the umerus; forequarter perimeter in the intermediate part of the umerus, involving the muscles that cover this region; and round thickness, measured with a compass by fixing one of the points in the most external portion of the topside and the other in the external face of the hindquarter, perpendicularly to the hindquarter.

In order to obtain the yield of each full primal cut, half carcasses were initially divided into forequarters and hindquarters cutting between the fifth and the sixth rib. The incision was made equally distant from those ribs, reaching the sternum (breast) and the backbone, at the fifth intervertebral space. The forequarter corresponds to the anterior part and the hindquarter to the posterior part of a half carcass. The hindquarter was subdivided in hindquarter and sidecut, cutting from the posterior extremity of the flank stake at the precrural lymphatic ganglion to the iliac tuberosity, following a straight line up to the sixth rib, approximately $32 \mathrm{~cm}$ from the dorsal line.

The hindquarters were deboned first. Hindquarters were weighed and deboned on the same shift and by the same operators, aiming at maintaining the same cutting and trimming standard when preparing the parts, producing boneless beef (the t-bone steak remained in the wide hindquarter and was prepared with bone in), edible trimmings (edible meat + fat trimmings), discarded trimmings (excessive fat trimmings + tallow + membranes), discarded bone, and weight loss inherent to the deboning process. A typical deboning standard for the domestic market was used, with moderate to close trim, complying with the demands for the production of branded vacuum-packed beef. Meat cuts and edible trimmings were weighed, and consisted of yield meat, summing up the parts sold for human consumption. Discarded bone and trimmings were also weighed to calculate the participation of each fraction relative to cold carcass weight.

The same procedures were used for the forequarters, which produced all the boneless cuts and foreribs, as well as for the sidecut, except for short ribs and rib roast that, along with the T-bone steak, were the only meat cuts prepared and packaged with bone in.

A randomized complete design with 15 replications per treatment was applied. Data were submitted to analysis of variance, and means were compared by the Tukey test (SAS, 1997).

The following mathematical model was used:

$\mathrm{Y}_{\mathrm{ij}}=\mathrm{M}+\mathrm{C}_{\mathrm{i}}+\mathrm{E}_{\mathrm{ij}}$ where $\mathrm{Y}_{\mathrm{ij}}$ = dependent variables; $\mathrm{M}=$ mean of all observations; $\mathrm{C}=$ effect of the $\mathrm{i}^{\mathrm{th}}$ animal classe; $\mathrm{E}_{\mathrm{ij}}=$ random residual effect. 


\section{Results and Discussion}

The animals were not weighed individually. Upon arrival at the packing plant, each animal-class lot was weighed after 6-h fasting. Females weighed in average $496 \mathrm{~kg}$, and males, $494 \mathrm{~kg}$, with average hot carcass dressing percentage of $50.01 \%$ and $53.24 \%$, respectively. Restle et al. (2002) observed average hot carcass dressing percentages of $50.12 \%$ for Charolais and Nellore purebred cows, and $51.30 \%$ for crossbred Charolais $\times$ Nellore cows.

The males presented higher carcass weight, better conformation, and lower chilling loss compared to the females, but were not different as to fat cover (Table 1 ). The inferior conformation of the females and superior conformation of the males, which are typical of these animal classes, often is negatively correlated with chilling loss due to the difference in carcass specific surface. Fat cover was not different between these animal classes, and presented, on a 0 to 4 scale, average values of 2.25 and 2.02 for the females and males, respectively, corresponding to 5-6 mm of fat cover, which is desired by the beef packing industry.

Evaluating young and super-young steer carcasses, Pacheco et al. (2005) showed that those with better conformation presented lower chilling loss, as well as no correlation between fat thickness and carcass drip loss during chilling. Vaz \& Restle (2005) and Menezes et al. (2005) also obtained a higher correlation of chilling loss with carcass conformation and hindquarter thickness than with fat cover thickness.
The steer carcasses were shorter, with longer and higher perimeter forelimbs and thicker rounds compared to the cow carcasses (Table 2).

When comparing Hereford cows to 24-month-old steers from the same herd, Vaz et al. (2002) observed higher slaughter weights and longer carcasses in cows, indicating that the steers were still growing, as mature males are expected to be heavier and to have longer carcasses (Di Marco, 1996). Restle et al. (2001b) also found that cows slaughtered at seven years of age or older were heavier and longer than those slaughtered at four years of age.

The coefficients of variation of edible trimmings, discarded trimmings and inherent losses are typically high due to the lack of a definition line when cutting between trimmings and inherent losses, which absorb all weighing failures, evaporation, and any tissue disappearance.

The cows presented higher sidecut yield (Table 3). Coutinho Filho et al. (2006), worked with young (17-monthold) Santa Gertrudis non-castrated males and females from the same herd and also obtained significantly higher sidecut yield in females (50.0\%) compared to males (48.1\%). On the other hand, Vaz et al. (2002) did not detect any differences in hindquarter yield when analyzing the carcasses of 24-monthold Hereford cows and steers and obtained values of 48.5 and 48.9\%, respectively. Cruz et al. (2004), distributed purebred and crossbred steers into three different slaughter weights, and observed that, in general, hindquarter and forequarter and/or rib yields increased as slaughter weight increased.

Several studies have shown the influence of genetic group on the yield of different cuts. When evaluating

Table 1 - Carcass traits, according to animal class

\begin{tabular}{|c|c|c|c|c|c|}
\hline \multirow[t]{2}{*}{ Trait } & \multicolumn{2}{|c|}{ Animal class } & \multirow[t]{2}{*}{ Mean } & \multirow[t]{2}{*}{$\mathrm{CV} \%$} & \multirow[t]{2}{*}{$\mathrm{P}$ value } \\
\hline & Cows & Steers & & & \\
\hline Half hot carcass, $\mathrm{kg}$ & $124.0 \mathrm{~b}$ & $131.5 a$ & 127.77 & 7.16 & 0.031 \\
\hline Chilling loss, \% & $2.26 \mathrm{a}$ & $1.91 \mathrm{~b}$ & 2.09 & 10.95 & 0.001 \\
\hline Conformation, score ${ }^{1}$ & $5.13 \mathrm{~b}$ & $10.81 \mathrm{a}$ & 7.97 & 33.89 & 0.001 \\
\hline Fat cover, score ${ }^{2}$ & 2.25 & 2.02 & 2.13 & 37.51 & 0.439 \\
\hline
\end{tabular}

Means followed by different letters in the same trait are different by the Tukey test $(\mathrm{P}<0.05)$.

11 to 18 score scale: 4 a $6=$ poor; 7 a $9=$ regular; 10 a $12=$ good.

20 to 4 score scale, with $1=\operatorname{regular}(3-4 \mathrm{~mm}) ; 2=\operatorname{good}(5-6 \mathrm{~mm}) ; 3=\operatorname{excellent}(7-8 \mathrm{~mm})$.

Table 2 - Carcass measurements (cm) according to animal class

\begin{tabular}{|c|c|c|c|c|c|}
\hline \multirow[t]{2}{*}{ Item } & \multicolumn{2}{|c|}{ Animal class } & \multirow[t]{2}{*}{ Mean } & \multirow[t]{2}{*}{$\mathrm{CV} \%$} & \multirow[t]{2}{*}{$P$ value } \\
\hline & Cows & Steers & & & \\
\hline Carcass length & $137.67 \mathrm{a}$ & $128.60 \mathrm{~b}$ & 133.14 & 5.35 & 0.001 \\
\hline Forelimb length & $38.53 b$ & $40.87 \mathrm{a}$ & 39.70 & 3.35 & 0.001 \\
\hline Forelimb perimeter & $34.60 \mathrm{~b}$ & $37.20 \mathrm{a}$ & 35.90 & 3.80 & 0.001 \\
\hline Round thickness & $23.80 \mathrm{~b}$ & $25.13 \mathrm{a}$ & 24.47 & 3.54 & 0.009 \\
\hline
\end{tabular}

Means followed by different letters in the same trait are different by the Tukey test $(\mathrm{P}<0.05)$. 
Table 3 - Mean yield of cuts prepared from the hindquarter as a percentage of cold carcass, according to animal class

\begin{tabular}{|c|c|c|c|c|c|}
\hline \multirow[t]{2}{*}{ Item } & \multicolumn{2}{|c|}{ Animal class } & \multirow[t]{2}{*}{ Mean } & \multirow[t]{2}{*}{$\mathrm{CV} \%$} & \multirow[t]{2}{*}{$\mathrm{P}$ value } \\
\hline & Cows & Steers & & & \\
\hline Whole hindquarter & $48.93 a$ & $48.13 b$ & 48.53 & 2.11 & 0.039 \\
\hline Flat & 4.02 & 4.00 & 4.01 & 5.14 & 0.828 \\
\hline Topside & 6.51 & 6.51 & 6.51 & 5.53 & 0.989 \\
\hline Eye round & 1.72 & 1.83 & 1.78 & 11.43 & 0.153 \\
\hline Shank & 1.57 & 1.58 & 1.58 & 7.22 & 0.756 \\
\hline Edible trimmings & 1.30 & 1.23 & 1.27 & 26.85 & 0.538 \\
\hline Discarded trimmings & 0.98 & 0.96 & 0.97 & 25.53 & 0.857 \\
\hline Discarded bone & $5.18 b$ & $5.66 \mathrm{a}$ & 5.42 & 8.04 & 0.005 \\
\hline Full rump & $7.36 \mathrm{a}$ & $6.90 \mathrm{~b}$ & 7.13 & 6.40 & 0.011 \\
\hline Rump uk trim & $2.80 \mathrm{a}$ & $2.66 \mathrm{~b}$ & 2.73 & 4.92 & 0.016 \\
\hline Discarded bone & $1.49 \mathrm{a}$ & $1.30 \mathrm{~b}$ & 1.40 & 11.74 & 0.001 \\
\hline Full loin & $14.68 \mathrm{a}$ & $13.93 b$ & 14.31 & 5.30 & 0.009 \\
\hline Tenderloin & 1.40 & 1.37 & 1.39 & 8.46 & 0.469 \\
\hline Tenderloin side chain & 0.23 & 0.24 & 0.24 & 38.43 & 0.662 \\
\hline Striploin & $3.92 \mathrm{a}$ & $3.65 b$ & 3.79 & 9.47 & 0.048 \\
\hline Cuberoll & 1.68 & 1.70 & 1.69 & 14.66 & 0.862 \\
\hline Cap of cube roll & 0.95 & 0.97 & 0.96 & 16.34 & 0.666 \\
\hline Rib & 2.22 & 2.18 & 2.20 & 14.17 & 0.740 \\
\hline Nerve & $0.07 \mathrm{~b}$ & $0.08 \mathrm{a}$ & 0.08 & 22.76 & 0.026 \\
\hline Edible trimmings & 0.96 & 0.88 & 0.92 & 21.72 & 0.280 \\
\hline Discarded trimmings & $0.54 \mathrm{a}$ & $0.31 b$ & 0.43 & 44.78 & 0.003 \\
\hline Discarded bone & 2.70 & 2.51 & 2.61 & 11.13 & 0.077 \\
\hline Inherent losses & 0.01 & 0.02 & 0.02 & 165.22 & 0.203 \\
\hline
\end{tabular}

Means followed by different letters in the same trait are different $(\mathrm{P}<0.05)$ by the Tukey test.

animals of the breeds Caracu, Nellore Seleção, and Nellore Controle, slaughtered at 22 months of age, with average cold half carcass weight of 149.5, 143.7, and $124.6 \mathrm{~kg}$ and fat cover of 4.5, 5.8 and $6.6 \mathrm{~mm}$, Bonilha et al. (2007) obtained hindquarter yields of $44.3,46.1$ and $46.7 \%$, respectively.

Restle et al. (2001a) observed higher hindquarter yield in Charolais heifers (36 months of age) $(49.45 \%)$ as compared to Charolais $\times$ Nellore $(48.57 \%)$ heifer of the same age and from the same herd. Higher hindquarter yield of Charolais cows (47.14\%) compared to Nellore cows (45.98\%) was reported by Restle et al. (2002).

There are no available studies in the Brazilian literature on sub-primal hindquarter cuts (round shank on, full rump, and loin) and their subdivisions into prepared meat cuts, edible trimmings, and discarded products that sum up the hindquarter percentage value. In the international literature, Koch et al. (1981, 1982) made these evaluations, but used animals with higher finishing and US cut and deboning standards, and did not define the methodology used for trimming, and therefore their results cannot be compared with those obtained in the present study.
Round shank was similar in yield between the steers and cows, as well for full rump cuts, except for discarded bone, which was higher for males. Cows presented higher full round, striploin, and full rump UK trim yields, whereas the steers had higher yield of bone discarded from the round. Full loin, striploin, and trimming yields were higher in the cows due to their higher length compared to male carcasses (Table 2).

Junqueira et al. (1998) also found higher full rump, rump cap, tenderloin, and striploin yields in females compared to contemporary non-castrated males. Studying carcass traits of males with $7.70 \mathrm{~mm}$ fat thickness and females with $7.29 \mathrm{~mm}$ fat thickness, Coutinho Filho et al. (2006) reported levels slightly higher than 5 to $7 \mathrm{~mm}$, which are the values that prevent trimming losses the most. These authors observed that females presented higher tenderloin, knuckle, and edible trimming yields, whereas males had higher eye round yield. As to edible trimmings and discarded bone, Coutinho et al. (2006) did not find significant difference between males and females, with 10.08 and $10.31 \%$ of bone, 3.21 and $4.30 \%$ discarded trimmings, and 2.91 and $2.84 \%$ of edible trimmings for males and females, respectively. 
Evaluating non-castrated Nellore, Nellore $\times$ Simmental, Simmental, and Simbrasil males, Bianchini et al. (2007) found significant differences in cuts prepared from the hindquarter in absolute values, but not when these were expressed relative to cold carcass weight.

The results of hindquarter cut yields relative to the full hindquarter are not directly shown, but were calculated from the obtained data (Table 3). The hindquarter yielded $70.91 \%$ prepared meat cuts, $19.41 \%$ bones, and $9.68 \%$ total trimmings ( $4.06 \%$ edible $+5.62 \%$ discarded trimmings). This allowed us to compared our data with those obtained by Tarouco et al. (2007), who deboned the hindquarter of 102 Braford animals, which, however, were younger (12 months of age) and lighter (158.25 kg carcass) than the steers used in the present experiment, and obtained $68.53 \%$ prepared cut yield, $20.76 \%$ bones, and $10.82 \%$ total trimmings, which were very similar to our results.
The full forequarter deboning yield was higher in the steers due to higher shoulder yield, whereas chuck yield was similar to that of the cows (Table 4). The steers also presented higher shoulder discarded bone, which was the only difference obtained in the forequarter deboning products between males and females. Junqueira et al. (1998) reported higher yields of the forequarter and its respective meat cuts (chuck, neck, brisket, and shoulder) and bones in non-castrated males as compared to females.

Coutinho Filho et al. (2006) found higher forequarter yield in males (38.60\%) than in females (35.67\%), whereas Vaz et al. (2002), analyzing carcass traits of 24-month-old Hereford cows and steers, did not find any difference in forequarter yield, with 36.36 and $36.96 \%$, respectively.

The total sidecut yield was similar between the cows and steers. The cows presented higher discarded trimming yield, which the only difference was in the production of prepared

Table 4 - Yield of forequarter meat expressed as a percentage of cold carcass according to animal class

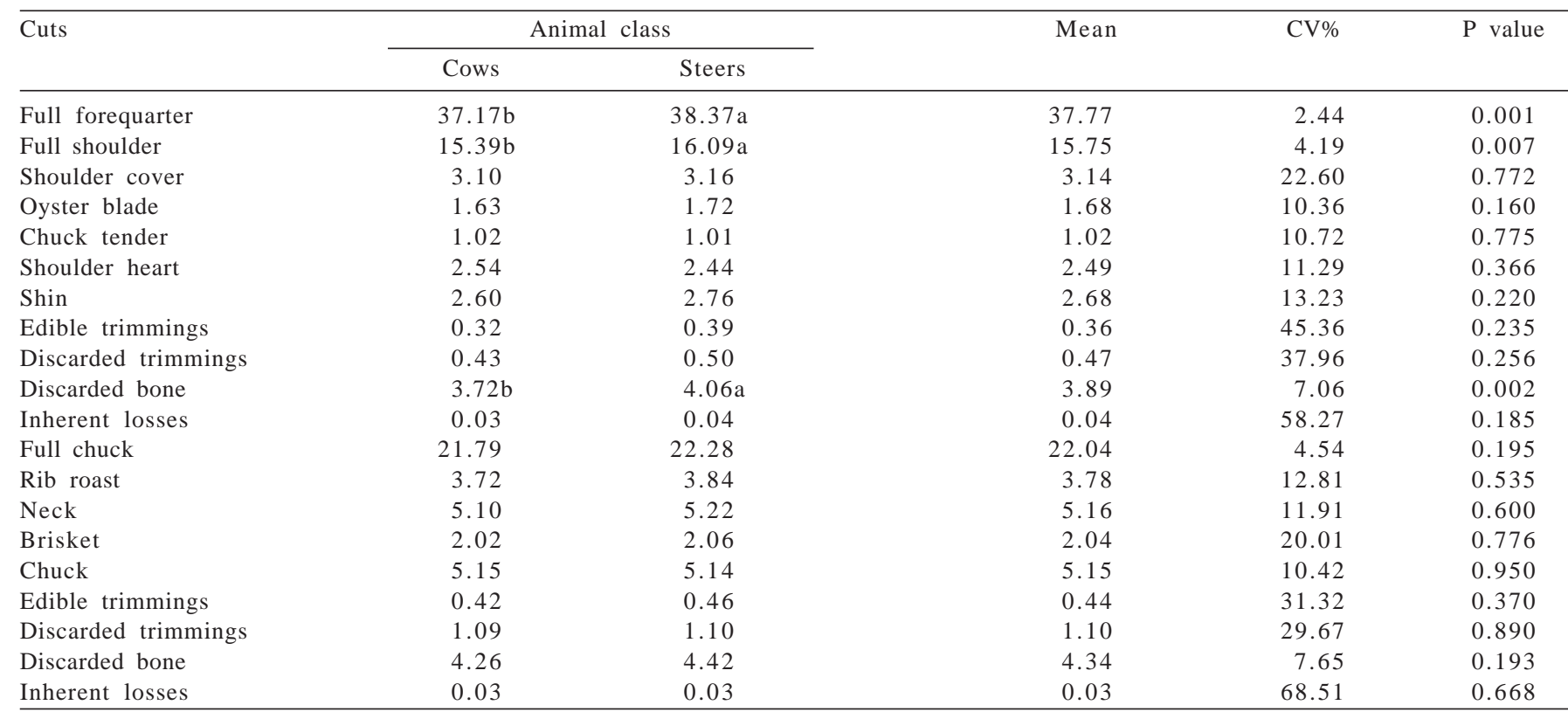

Means followed by different letters in the same trait are different by the Tukey test $(\mathrm{P}<0.05)$.

Table 5 - Yield of rib yield meat expressed as a percentage of cold carcass according to each animal class

\begin{tabular}{|c|c|c|c|c|c|}
\hline \multirow[t]{2}{*}{ Cuts } & \multicolumn{2}{|c|}{ Animal class } & \multirow[t]{2}{*}{ Mean } & \multirow[t]{2}{*}{$\mathrm{CV} \%$} & \multirow[t]{2}{*}{$\mathrm{P}$ value } \\
\hline & Female & Male & & & \\
\hline Total sidecut & 13.89 & 13.50 & 13.70 & 5.97 & 0.221 \\
\hline Short ribs & 5.48 & 5.46 & 5.47 & 8.70 & 0.927 \\
\hline Cube roll cover & 3.67 & 3.38 & 3.53 & 12.26 & 0.082 \\
\hline Subcutaneous muscle & 1.14 & 1.21 & 1.18 & 9.93 & 0.109 \\
\hline Thin flank & 1.77 & 1.77 & 1.77 & 12.31 & 0.996 \\
\hline Flank steak & 0.44 & 0.43 & 0.44 & 11.26 & 0.464 \\
\hline Edible trimmings & 0.32 & 0.40 & 0.36 & 39.19 & 0.146 \\
\hline Discarded trimmings & $1.06 \mathrm{a}$ & $0.85 b$ & 0.96 & 20.94 & 0.008 \\
\hline Discarded bone & - & - & - & - & - \\
\hline Inherent losses & 0.02 & 0.01 & 0.01 & 89.95 & 0.081 \\
\hline
\end{tabular}

Means followed by different letters in the same trait are different by the Tukey test $(\mathrm{P}<0.05)$. 
rib cuts (Table 5). Vaz et al. (2002) analyzed carcass traits of 24-month-old Hereford culled cows and steers and observed significantly higher rib yield in the cows (16.92\%) compared to the steers (14.92\%), as did Coutinho Filho et al. (2006), with $14.31 \%$ for females and $13.28 \%$ for males.

The yields of cuts prepared with each primal cut and their sub-primal cuts did not differ between the males and females (Table 6). The males tended to have lower yield of the cuts prepared from the hindquarter and higher forequarter yield, as the primal cuts were different when whole (Tables 3 and 4 ).

The yield of discarded trimmings from the hindquarter and the sidecut (Table 7) was higher in the cows; however, it did not result in total discarded trimmings (Table 8). Bonilha et al. (2007) found an average of $11.3 \%$ trimmings in their study, but they did not differentiate it in edible and discarded trimmings. In the present study, the sum of edible trimmings (Tables 3, 4, and 5) was 3.89\%, which, added to $4.32 \%$ discarded trimmings (Table $3,4,5$ ), resulted in $8.21 \%$ total trimmings, a value that is slightly lower than that reported by Bonilha et al. (2007). This difference may be related to the fact that the animals had an average of $2 \mathrm{~mm}$ fat cover or to the closeness of trimming used in the present study.

The total discarded bone yield (Table 7) was not different between animal classes, despite the higher forequarter discarded bone yield in the steers. In the study by Bonilha et al. (2007), an average of $19.13 \%$ total bone was determined for the three evaluated genetic groups, with $1.96 \%$ corresponding to rib bones. In the present study, total average bone yield was $17.65 \%$ (Table 8), not taking into consideration rib bones, as the rib cuts were prepared with bone in. Summing the $1.96 \%$ rib bone yield obtained by

Table 6 - Yield of cuts prepared from the primal cuts expressed as a percentage of cold carcass according to animal class

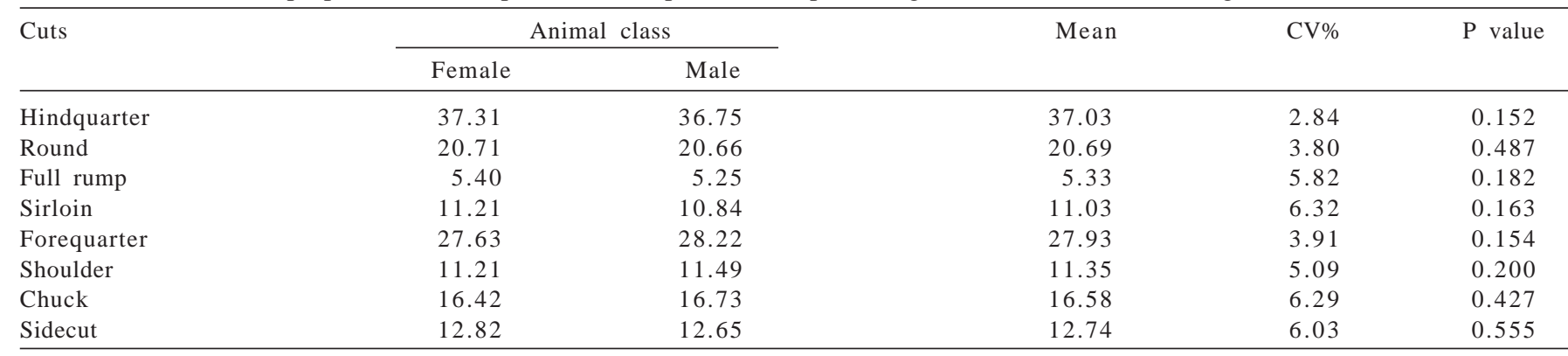

Table 7 - Yield of discarded trimmings and bones derived from the primal cuts expressed as a percentage of cold carcass according to animal class

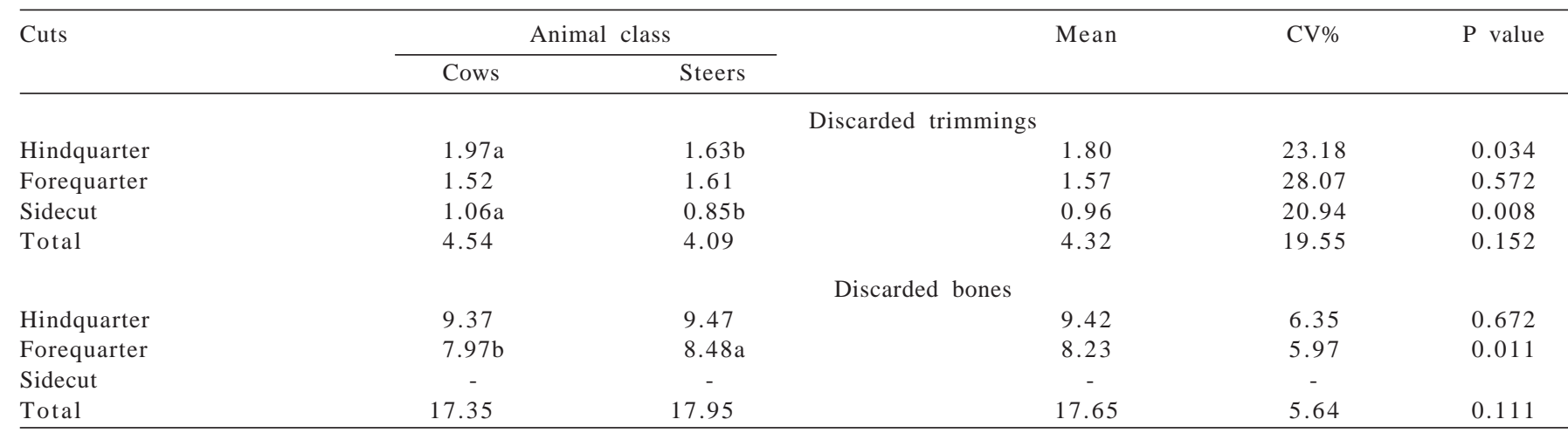

Means followed by different letters in the same trait are different by the Tukey test $(\mathrm{P}<0.05)$.

Table 8 - Average yield of products derived from deboning expressed as a percentage of cold carcass according to animal class

\begin{tabular}{|c|c|c|c|c|c|}
\hline \multirow[t]{2}{*}{ Parameter } & \multicolumn{2}{|c|}{ Animal class } & \multirow[t]{2}{*}{ Mean } & \multirow[t]{2}{*}{ CV\% } & \multirow[t]{2}{*}{$\mathrm{P}$ value } \\
\hline & Cows & Steers & & & \\
\hline Yield meat & 77.77 & 77.62 & 77.70 & 1.64 & 0.752 \\
\hline Discarded trimmings & 4.54 & 4.09 & 4.32 & 19.55 & 0.152 \\
\hline Inherent losses & 0.34 & 0.34 & 0.34 & 85.13 & 0.871 \\
\hline Total & 100.00 & 100.00 & 100.00 & - & - \\
\hline
\end{tabular}


Bonilha et al. (2007) to the bone yield obtained in the present study, total bone adds up to $19.61 \%(17.65+1.96 \%)$, which is similar to that found by the aforementioned authors. Ledic et al. (2000) obtained $72.59 \%$ edible meat, $19.64 \%$ bones, and $4.21 \%$ discarded trimmings.

Studies that applied the direct deboning method (Osório et al., 1995; Junqueira et al., 1998; Ledic et al., 2000; Coutinho Filho et al., 2006; Bonilha et al., 2007; Tarouco et al., 2007) found lower percentages of edible cuts, and higher percentages of bone than those that reported the method proposed by Hankins \& Howe (1946) (Perotto et al., 2000; Feijó et al., 2001; Vaz \& Restle, 2005; Kuss et al., 2005; Canesin et al., 2006). The studies using the direct assessment method for deboning obtained $19.08 \%$ average bone yield, whereas those applying the HH method achieved $16.85 \%$, resulting in a 3.23\% difference. This suggests that the bone fraction may be underestimated and the edible portion, overestimated, in studies applying the direct method. However, Paulino et al. (2005) studied the validation of the equations of Hankins \& Howe (1946) and concluded that the $\mathrm{HH}$ section $\left(9^{\text {th }}, 10^{\text {th }}\right.$, and $11^{\text {th }}$ rib $)$ provided a satisfactory estimate of the physical composition of the carcass of crossbred Nellore cattle weighing between 223.50 and $421.50 \mathrm{~kg}$. None of these parameters presented any differences $(\mathrm{P}>0.05)$ between animal classes.

According to Luchiari Filho (2000), males and females have similar production of edible portions, as well as similar yield of the most valued cuts. Junqueira et al. (1998) observed higher yield of prepared meat cuts + edible trimmings in non-castrated males (75.33\%) compared to females (73.72\%) of the same age and genetic group due to the higher yield of discarded trimmings in females (8.03 vs.6.71\%). The authors argued that this resulted from the thicker fat cover in females $(8.6 \mathrm{~mm})$ as compared to males $(4.5 \mathrm{~mm})$, which was not the case in the present study (Table 1). Relating different fat covers measured on the loin with deboning yields, Parrett et al. (1985) found significant differences in fat, lean meat, and bone values in animals with fat covers of $5 \mathrm{~mm}, 10 \mathrm{~mm}$, and $15 \mathrm{~mm}$.

\section{Conclusions}

The male carcasses presented better conformation, lower chilling weight loss, were shorter, and had longer and thicker limbs than the female carcasses. Compared to the males, the female carcasses had similar rib yield, lower forequarter yield, and higher hindquarter yield, with higher full rump, loin, eye of full rump, tail of round, and striploin. The total yield of yield meat, discarded bone, discarded trimmings, and losses inherent to the deboning process was not different between male and female carcasses.

\section{Literature Cited}

BIANCHINI, W.; SILVEIRA, A.C.; JORGE, A.M. et al. Efeito do grupo genético sobre as características de carcaça e maciez da carne fresca e maturada de bovinos superprecoces. Revista Brasileira de Zootecnia, v.36, n.6, p.2109-2117, 2007.

BONILHA, S.F.M.; PACKER, I.U.; FIGUEIREDO, L.A. et al. Efeitos da seleção para peso pós-desmame sobre características de carcaça e rendimento de cortes cárneos comerciais de bovinos. Revista Brasileira de Zootecnia, v.36, n.5, p.1275-1281, 2007.

CANESIN. R.C.; BERCHIELLI, T.T.; ANDRADE, P. et al. Características da carcaça e da carne de novilhos mantidos em pastagem de capim-marandu submetidos a diferentes estratégias de suplementação. Revista Brasileira de Zootecnia, v.35, n.6, p.2368-2375, 2006.

COUTINHO FILHO, J.L.V.; PERES, R.M.; JUSTO, C.L. Produção de carne de bovinos contemporâneos, machos e fêmeas, terminados em confinamento. Revista Brasileira de Zootecnia, v.35, n.5, p.2043-2049, 2006.

CRUZ, G.M.; TULLIO, R.R.; ESTEVES, S.N. et al. Peso de abate de machos não-castrados para produção do bovino jovem. 2. Peso, idade e características da carcaça. Revista Brasileira de Zootecnia, v.33, n.3, p.646-657, 2004.

DI MARCO, O.N. Crecimiento de vacunos para carne. Mar del Plata: Balcarce, 1998. 246p.

FEIJÓ, G.L.D.; EUCLIDES FILHO, K.; EUCLIDES, V.P.B. et al. Avaliação das carcaças de novilhos F1 Angus-Nellore em pastagens de Brachiaria decumbens submetidos a diferentes regimes alimentares. Revista Brasileira de Zootecnia, v.30, n.3, p.1015-1020, 2001 (supl.1).

HANKINS, P.; HOWE, P.E. Estimation of composition of beef carcasses and cuts. Washington, D.C.: USDA, 1946. 20p. (Tecnical Bulletin, 926)

JUNQUEIRA, J.O.B.; VELLOSO, L.; FELÍCIO, P.E. Desempenho, rendimentos de carcaça e cortes de animais, machos e fêmeas, mestiços Marchigiana x Nellore, terminados em confinamento. Revista Brasileira de Zootecnia, v.27, n.6, p.1199-1205, 1998.

KOCH, R.M.; DIKEMAN, M.E.; CUNDIFF, L.V. Characterization of biological types of cattle (cycle II). V. Carcass wholesale cut composition. Journal of Animal Science, v.53, n.4, p.992-999, 1981

KOCH, R.M.; DIKEMAN, M.E.; CUNDIFF, L.V. Characterization of biological types of cattle (cycle III). V. Carcass wholesale cut composition. Journal of Animal Science, v.54, n.6, 1982.

KUSS, F.; RESTLE, J.; BRONDANI, I.L. et al. Características da carcaça de vacas de descarte de diferentes grupos genéticos terminadas em confinamento com distintos pesos. Revista Brasileira de Zootecnia, v.34, n.3, p.915-925, 2005.

LEDIC, I.L.; TONHATI, H.; FERNANDES, L.O. Rendimento integral de bovinos após abate. Ciência Agrotécnica, v.24, n.1, p.272-277, 2000.

LUCHIARI FILHO, A. Pecuária da carne bovina. 1.ed. São Paulo: A. Luchiari Filho, 2000. 134p.

MENEZES, L.F.G.; RESTLE, J.; BRONDANI, I.L. et al. Características da carcaça de novilhos de gerações avançadas do cruzamento alternado entre as raças Charolês e Nellore, terminados em confinamento. Revista Brasileira de Zootecnia, v.34, n.3, p.934-945, 2005.

MÜLLER, L. Normas para avaliação de carcaças e concurso de carcaça de novilhos. 2.ed. Santa Maria: Universidade Federal de Santa Maria, 1987. 31p.

OSÓRIO, J.C.S.; JARDIM, P.O.; GUERREIRO, J.L.V. et al. Desenvolvimento dos cortes da carcaça em bovinos Hereford. Revista Brasileira de Agrociência, v.1, p.43-47, 1995.

PACHECO, P.S.; SILVA, J.H.S.; RESTLE, J. et al. Características quantitativas da carcaça de novilhos jovens e superjovens de diferentes grupos genéticos. Revista Brasileira de Zootecnia, v.34, n.5, p.1666-1677, 2005. 
PARRETT, D.F.; ROMANS, J.R.; BECHTEL, P.J. et al. Beef steers slaughtered at three fat-constant end points: II. Wholesale-cut composition and predictors of percentage carcass fat and boneless retail cuts. Journal of Animal Science, v.61, n.2, 1985.

PAULINO, P.V.R.; COSTA, M.A.L.; VALADARES FILHO, S.C. et al.Validação das equações desenvolvidas por Hankins e Howe para predição da composição da carcaça de zebuínos e desenvolvimento de equações para estimativa da composição corporal. Revista Brasileira de Zootecnia, v.34, n.1, p.327-339, 2005.

PeRotTO, D.; MOLETTA, J.L.; CUBAS, A.C. Características quantitativas da carcaça de bovinos Charolês, Caracu e cruzamentos recíprocos terminados em confinamento. Revista Brasileira de Zootecnia, v.29, n.1, p.117-124, 2000.

RESTLE, J.; CERDÓTES, L.; VAZ, F.N. et al. Características de carcaça e da carne de novilhas Charolês e 3/4Charolês 1/4 Nellore, terminadas em confinamento. Revista Brasileira de Zootecnia, v.30, n.3, p.1065-1075, 2001a (supl. 1).

RESTLE, J.; VAZ, F.N.; ALVES FILHO, D.C. et al. Efeito da suplementação energética sobre a carcaça de vacas de diferentes idades, terminadas em pastagem cultivada de estação fria sob pastejo horário. Revista Brasileira de Zootecnia, v.30, n.3, p.1076-1083, 2001b (supl. 1).
RESTLE, J.; PASCOAL, L.L.; FATURI, C. et al. Efeito do grupo genético e da heterose nas características quantitativas da carcaça de vacas de descarte terminadas em confinamento. Revista Brasileira de Zootecnia, v.31, n.1, p.350-362, 2002 (supl.).

STATISTICAL ANALYSIS SYSTEMS - SAS. User's guide. Version 6. Cary: 1997. v.2, 1052p.

TAROUCO, J.U.; LOBATO, J.F.P.; TAROUCO, A.K. et al. Comparação entre medidas ultra-sônicas e da carcaça na predição da composição corporal em bovinos. Estimativas do peso e da porcentagem dos cortes comerciais do traseiro. Revista. Brasileira de Zootecnia, v.36, n.6, p.2092-2101, 2007.

VAZ, F.N.; RESTLE, J.; QUADROS, A.R.B. et al. Características da carcaça e da carne de novilhos e de vacas de descarte Hereford, terminadas em confinamento. Revista Brasileira de Zootecnia, v.31, n.3, p.1501-1510, 2002 (supl.).

VAZ, F.N.; RESTLE, J. Aspectos qualitativos da carcaça e da carne de machos Braford superprecoces, desmamados aos 72 ou 210 dias de idade. Revista Brasileira de Zootecnia, v.31, n.5, p.2078-2087, 2002.

VAZ, F.N.; RESTLE, J. Características de carcaça e da carne de novilhos Hereford terminados em confinamento com diferentes fontes de volumoso. Revista Brasileira de Zootecnia, v.34, n.1, p.230-238, 2005. 